\title{
PERANCANGAN APLIKASI PEMBACA WARNA UNTUK PENDERITA BUTA WARNA BERBASIS ANDROID
}

\section{DESIGN OF COLORS READER APLICATION FOR COLOR BLIND PEOPLE BASED ON ANDROID}

\author{
Aulya Ellanda ${ }^{1}$, Suci Aulia, ST,MT. ${ }^{2}$, Yuli Sun Hariyani, ST,MT. ${ }^{3}$ \\ Prodi D3 Teknik Telekomunikasi, Fakultas Ilmu Terapan \\ Universitas Telkom \\ 12aulyanew@gmail.com, ${ }^{2}$ suciaulia@ telkomuniversity.ac.id, ${ }^{3}$ yulisun@telkomuniversity.ac.id
}

\begin{abstract}
Abstrak
Penyandang cacat buta warna selalu mengalami kesulitan dalam hal membedakan warna dalam kehidupan sehari-harinya, sehingga dibutuhkan alat bantu bagi mereka. Dalam penelitian ini dibuat sebuah algorithma yang dapat berfungsi untuk membedakan warna, algorithma tersebut diaplikasikan kedalam sebuah android. Aplikasi ini membantu dalam hal membedakan warna (merah, hijau dan biru) dengan pola image processing. Output dari aplikasi ini berupa text dan voice yang merupakan hasil deteksi dari input (captured image) secara langsung menggunakan smartphone android. Hasil yang diperoleh dari penelitian ini, yaitu tingkat akurasi total sistem $85 \%$ dengan waktu komputasi 6,67 detik dan jarak terjauh $20 \mathrm{~cm}$.
\end{abstract}

Kata kunci : image processing, android, mobile, smartphone, buta warna

\begin{abstract}
For color blindness they always have difficulty to distinguish colors in daily life, so it is necessary tools for them. In this research has made an algorithm that can distinguish colors, The algorithm is applied into an android. This application can help in distinguishing colors (red, green and blue) with patterns of image processing. The output of this applications are text and voice as a result of the input detection (captured image) directly using android smartphone.The results obtained from this research, the system has accuracy $85 \%$ with computing time \pm 9 second.
\end{abstract}

Keywords: image processing, android, mobile, smartphones, color blindness

\section{PENDAHULUAN}

Buta warna atau Color Blindness adalah salah satu kelainan mata yang sebagian besar disebabkan oleh faktor genetik.Walaupun tidak terlalu sering, buta warna juga dapat terjadi bukan karena faktor keturunan. Pada kasus buta warna yang bukan karena genetik, kelainan hanya terjadi pada salah satu mata saja dan kondisi ini bisa terus memburuk. Pasien dengan gangguan persepsi warna yang disebabkan oleh penyakit sering mengalami kesulitan membedakan warna biru, merah dan hijau. Sedangkan pada kasus buta warna karena faktor keturunan, gangguan terjadi pada kedua mata, namun tidak mengalami penurunan. Buta warna lebih banyak dialami pria daripada wanita. Banyak orang beranggapan seseorang yang mengalami buta warna hanya bisa melihat warna hitam dan putih, layaknya melihat TV hitam putih. Anggapan tersebut tidaklah benar. Jarang sekali ditemukan seseorang mengalami buta warna total (tidak memiliki persepsi warna sedikitpun). 
Orang dengan kelainan buta warna memang kadang-kadang mengalami kesulitan untuk membedakan warna pakaiannya, namun hal itu bukanlah masalah yang berat. Ia masih dapat melakukan kegiatan normal, bahkan mengendarai mobil.Memang kadang ia mengalami kesulitan membedakan warna merah, kuning dan hijau pada lampu lalu lintas, tapi hal tersebut dapat diatasi dengan mengingat posisi lampu yang berwarna merah, kuning, dan hijau

Untuk memahami penyebab terjadinya buta warna,kita perlu mengetahui bagian darimata itu sendiri.Pada bagian tengah retina,terdapat photoreceptor atau cone (seperti kantung) yang memungkinkan kita untuk bisa membedakan warna. Photoreceptor ini terdiri dari tiga pigmen warna yaitu merah, hijau dan biru.Gangguan persepsi terhadap warna terjadi apabila satu atau lebih dari pigmen tersebut tidak ada atau sangat kurang. Mereka dengan persepsi warna normal disebut Trichromats.Mereka yang mengalami defisiensi salah satu pigmen warna disebut dengan Anomalous Trichromats.Tipe ini adalah yang paling sering ditemukan. Sedangkan mereka yang sama sekali tidak memiliki salah satu dari pigmen warna itu disebut drichromat.Tanda seorang mengalami buta warna tergandung pada beberapa faktor apakah kondisinya disebabkan faktor genetik, penyakit, dan tingkat buta warnanya sebagian atau total. Gejala umumnya adalah kesulitan membedakan warna merah dan hijau (yang paling sering terjadi), atau kesulitan membedakan warna biru dan hijau (jarang ditemukan). Gejala untuk kasus yang lebih serius berupa objek terlihat dalam bentuk bayangan abu-abu (kondisi ini sangat jarang ditemukan), dan penglihatan berkurang dengan latar belakang dan pertimbangan tersebut, maka penulis mencoba menawarkan suatu solusi dimana para penderita bisa mengetahui warna secara pasti dengan menggunakan alat pendeteksi warna ini.

Berdasarkan latar belakang di atas, maka munculah ide untuk membuat sistem yang dapat membantu penyandang cacat buta warna untuk membedakan warna, dalam hal ini adalah warna dasar yaitu merah, hijau, dan biru. Sistem ini bekerja dengan memanfaatkan teknologi terbarukan yang sudah user friendly dikalangan masyarakat dan pada umumnya hamir semua orang sudah memiliki, yaitu smartphone berbasis android. Sistem ini berupa aplikasi, dimana inputnya diambil langsung dengan meng-capture objek kemudiaan diproses oleh aplikasi. Outputnya berupa text dan voice yang menyebutkan warna hasil deteksi dari input tersebut.

\section{ANDROID DAN PENGOLAHAN CITRA}

\subsection{Android}

Pengertian sistem aplikasi mobile merupakan aplikasi yang dapat digunakan walaupun pengguna berpindah dengan mudah dari satu tempat ketempat lain tanpa terjadi pemutusan atau terputusnya komunikasi. Aplikasi ini dapat diakses melalui perangkat nirkabel seperti pager, seperti telepon seluler dan PDA.[3]

Android adalah sebuah sistem operasi pada handphone yang bersifat terbuka dan berbasis pada sistem operasi Linux. Android bisa digunakan oleh setiap orang yang ingin menggunakannya pada perangkat mereka. Android menyediakan platform terbuka bagi para pengembang untuk menciptakan aplikasi mereka sendiri yang akan digunakan untuk bermacam peranti bergerak.[6]

\subsection{Pengolahan citra}

Pengolahan citra adalah proses pengolahan sinyal yang masukannya adalah citra. keluarannya dapat berupa citra atau sekumpulan karakteristik atau parameter yang berhubungan dengan citra. Istilah pengolahan citra digital secara umum didefinisikan sebagai pemrosesan citra dua dimensi dengan komputer. Dalam definisi yang lebih luas, pengolahan citra digital juga mencakup semua data dua dimensi. Citra digital adalah barisan bilangan nyata maupun kompleks yang diwakili oleh bit-bit tertentu. Citra sendiri adalah gambar dua dimensi yang dihasilkan dari gambar analog dua dimensi yang secara kontinu 
menjadi gambar diskrit melalu proses sampling. Gambar analog dibagi menjai $\mathrm{N}$ baris dan $\mathrm{M}$ kolom sehingga menjadi gambar diskrit. Persilangan antara baris dan kolom tertentu disebut dengan piksel. Terdapat beberapa istilah dalam pengolahan citra yaitu, sampling dan piksel.

Sampling adalah proses untuk menentukan warna pada piksel tertentu pada citra dari sebuah gambar yang kontinu. Pada proses sampling biasanya dicari warna rata-rata dari gambar analog yang kemudian dibulatkan. Proses sampling sering disebut juga sebagai proses digitalisasi. Ada kalanya dalam proses sampling, warna rata-rata yang didapat di realisasikan ke level warna tertentu. Contohnya apabila dalam citra/gambar hanya terdapat 16 tingkatan warna abu-abu, maka nilai rata-rata yang didapat dari proses sampling harus diasosiasikan ke 16 tingkatan warna tersebut. Proses mengasosiasikan warna rata-rata dengan tingkatan tertentu inilah yang kemudian disebut dengan kuantisasi. Sedangkan Piksel adalah kumpulan titik titik yang berwarna yang berdekatan sehingga terlihat membentuk sebuah gambar,semakin banyak jumlah piksel semakin tajam juga gambar yang di peroleh. Suatu gambar yang ada di dalam komputer sesungguhnya adalah kumpulan dari ribuan titik yang sangat kecil dan tiap-tiap titik tersebut memiliki warna tertentu. Titiktitik itulah yang disebut pixel. Setiap pixel mempunyai satu warna dan bergabung dengan pixel-pixel lainnya sehingga membentuk suatu pola dan menghasilkan gambar.

\subsection{RGB}

Setiap warna bisa disusun dari warna dasar. Untuk cahaya, warna dasar penyusunnya adalah warna Merah, Hijau dan Biru, atau lebih dikenal dengan istilah RGB (Red-Green-Blue). Warna adalah spektrum tertentu yang terdapat di dalam suatu cahaya sempurna (berwarna putih). Identitas suatu warna ditentukan panjang gelombang cahaya tersebut. Sebagai contoh warna biru memiliki panjang gelombang 460 nanometer.setiap warna mempunyai panjang gelombang dan frekuensi yang berbeda. Panjang gelombang warna yang masih bisa ditangkap mata manusia berkisar antara 380-780 nanometer.

Dalam peralatan optis, warna bisa pula berarti interpretasi otak terhadap campuran tiga warna primer cahaya: merah, hijau, biru yang digabungkan dalam komposisi tertentu. Misalnya pencampuran 100\% merah, $0 \%$ hijau, dan $100 \%$ biru akan menghasilkan interpretasi warna magenta. Gambar 1 memperlihatkan beberapa sampel warna komposisi RGB-nya skala 8 bit.
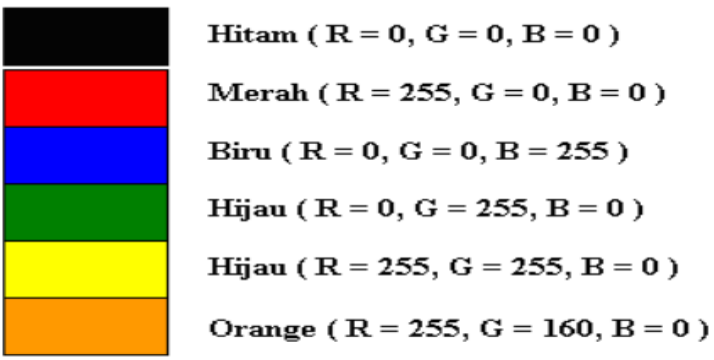

Gambar 1. Sampel warna dan Komposisinya

\subsection{Lux Meter[8]}

Alat ukur cahaya (lux meter) adalah alat yang digunakan untuk mengukur besarnya intensitas cahaya di suatu tempat. Besarnya intensitas cahaya ini perlu untuk diketahui karena pada dasarnya manusia juga memerlukan penerangan yang cukup. Untuk mengetahui besarnya intensitas cahaya ini maka diperlukan sebuah sensor yang cukup peka dan linier terhadap cahaya. Semakin jauh jarak antara sumber cahaya ke sensor maka akan semakin kecil nilai yang ditunjukkan lux meter. Ini membuktikan bahwa semakin jauh jaraknya maka intensitas cahaya akan semakin berkurang Alat ini didalam memperlihatkan hasil pengukurannya menggunakan format digital yang terdiri dari rangka, sebuah sensor. Sensor tersebut diletakan pada sumber cahaya yang akan diukur intenstasnya. 


\subsection{Pendeteksi Warna Berbasiskan Android}

\subsubsection{Pemodelan sistem}

Secara umum pemodelan sistem aplikasi pembaca warna ditunjukan pada Gambar 2 dibawah ini:

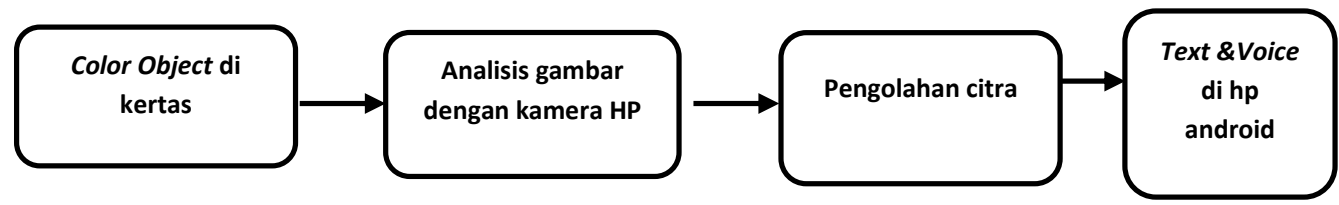

Gambar 2. Blok sistem perancangan aplikasi

Sistem aplikasi pembaca warna yang dirancang terbagi atas 3 blok, yaitu: blok input, blok kontrol dan blok output. Fungsi-fungsi blok tersebut antara lain :

- Blok Input digunakan untuk memberikan input data kepada blok kontrol.Input diberikan secara manual melalui pengambilan gambar oleh kamera smartphone.

- BlokKontrol menjalankan fungsi pengolahan data yang diterima dari blok input. Blok kontrol ini menggunakan Sistem Android yang penulisan program dilakukan pada software eclipse.setelah data diolah selanjutnya akan ditampilkan pada blok output.

- Blok Output berfungsi untuk menampilkan hasil pengolahan data blok kontrol.Blok output disini adalah smartphone yang akan menampilkan hasil pengolahan data berupa text dan voice. Alur perancangan aplikasi dapat dilihat pada Gambar 3 di bawah ini.

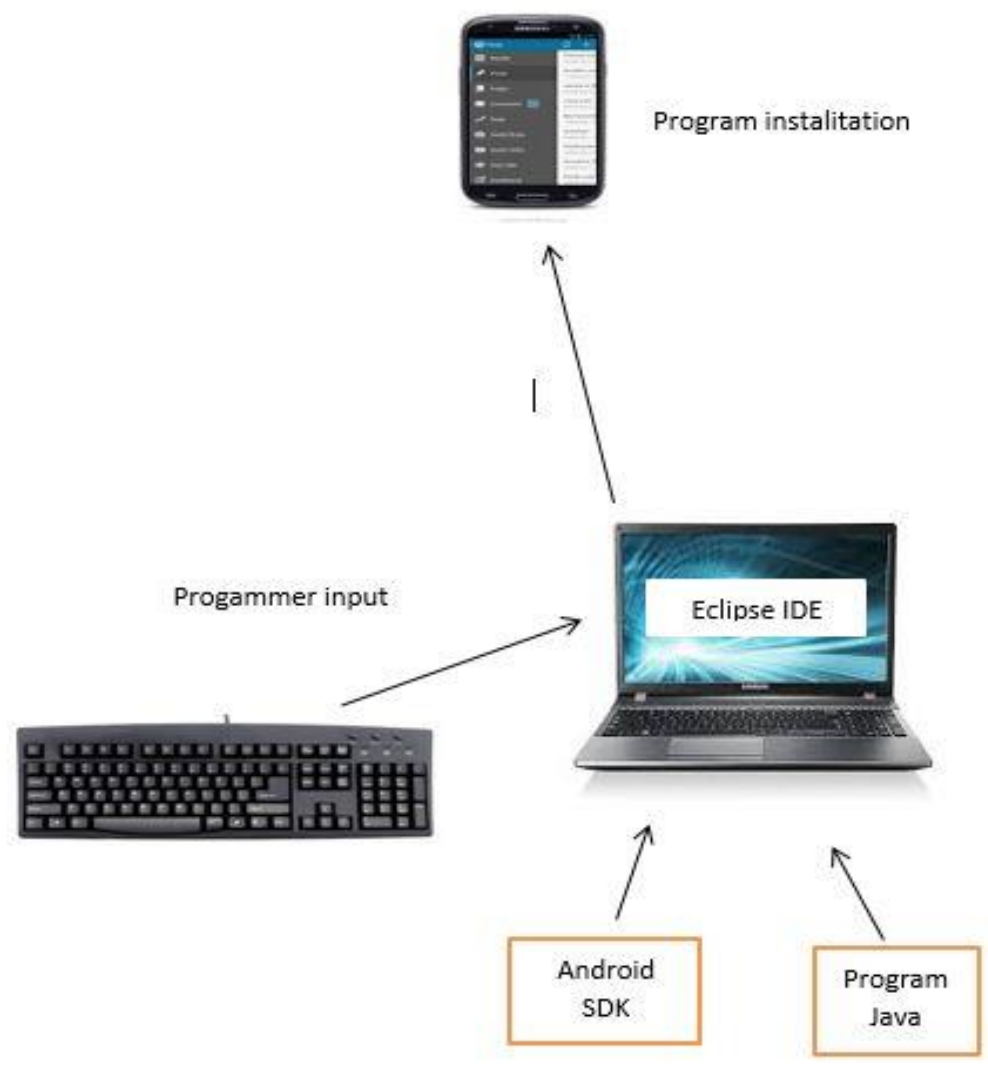

Gambar 3. Alur pembuatan aplikasi

\subsubsection{Diagram Alir Sistem}

Gambar.4 merupakan diagram alir kerja dari perangkat pembeda pembaca warna , yaitu sebagai berikut : 


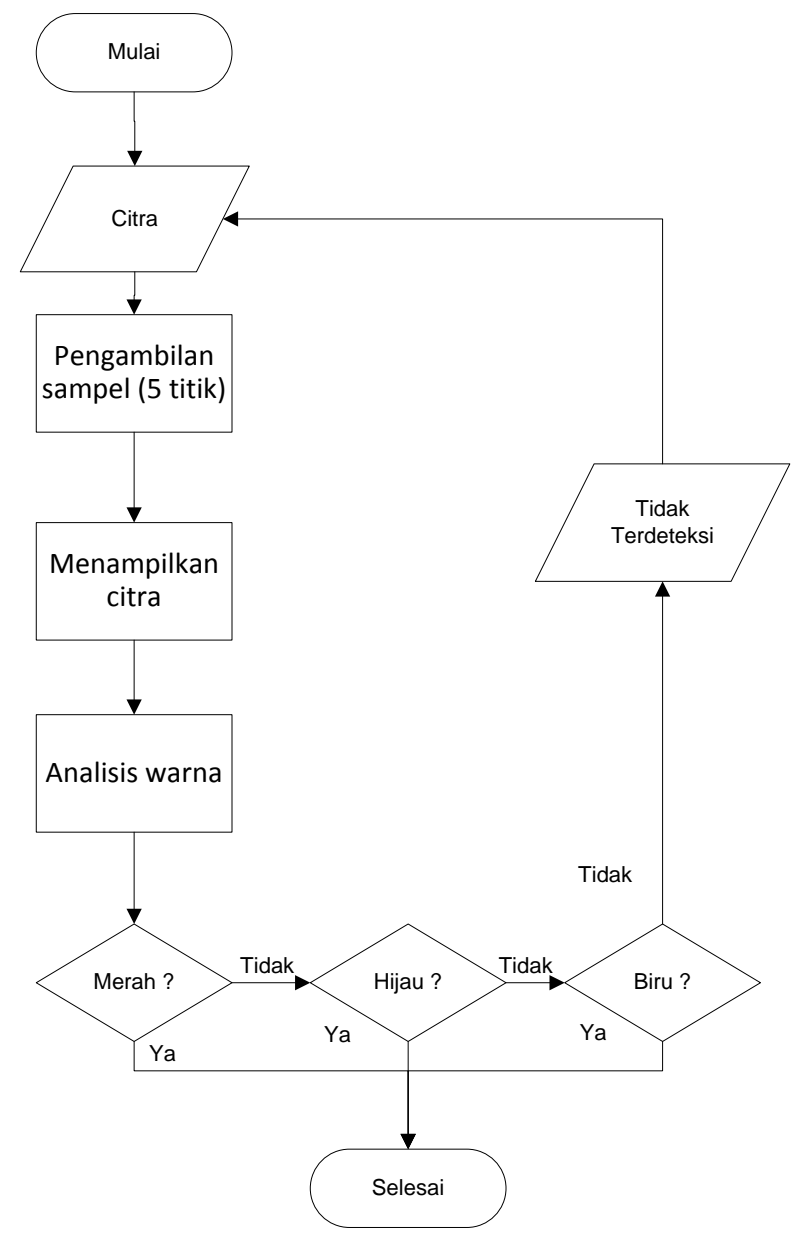

Gambar 4. Diagram alir kerja sistem

Berikut adalah cara kerja sistem android :

1) Pengambilan titik pada gambar

Sistem android akan mengambil beberapa titik untuk mendeteksi warna pada gambar yang sudah kita capture. Seperti yang terlihat pada Gambar 5 ada 5 titik yang diambil untuk mendeteksi warna.

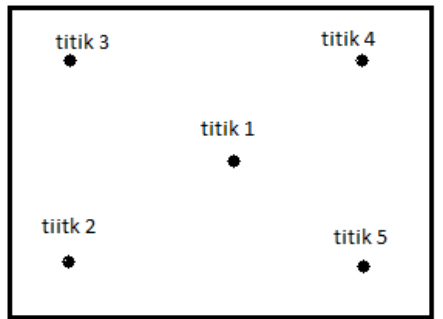

Gambar 5. Gambar pengambilan titik

2) Penentuan batas nilai pada warna

Penentuan batas nilai pada warna ini bertujuan untuk menentukan warna yang terdeteksi dengan melihat batas atas tertinggi dari nilai RGB.

Langkah 1 : mengambil titik sample lalu mengambil nilai pixel

Langkah 2 : mengumpulkan nilai piksel dari setiap kondisi

Langkah 3 : Mengambil nilai tertinggi dan terendah dari pengumpulan nilai tersebut. 


\subsubsection{Penentuan nilai batas ambang}

Dari data yang sudah diambil maka didapatkan nilai maksimum dan nilai minimum dari setiap kondisi untuk warna merah, hijau dan biru seperti yang ditunjukan pada Tabel 1.

Tabel 1. Penentuan nilai batas ambang

\begin{tabular}{|c|c|c|c|c|c|c|c|c|c|c|c|}
\hline \multirow{3}{*}{ Warna } & \multirow{3}{*}{$\begin{array}{c}\text { Komponen } \\
\text { Warna }\end{array}$} & \multicolumn{10}{|c|}{ Kondisi } \\
\hline & & \multicolumn{2}{|c|}{1} & \multicolumn{2}{|c|}{2} & \multicolumn{2}{|c|}{3} & \multicolumn{2}{|c|}{4} & \multicolumn{2}{|c|}{5} \\
\hline & & $\max$ & $\min$ & Max & $\min$ & $\max$ & $\min$ & Max & $\min$ & $\max$ & $\min$ \\
\hline \multirow{3}{*}{ Merah } & $\mathrm{R}$ & \#ca & \#bf & \#d4 & $\#$ a5 & $\# \mathrm{c} 3$ & \#8d & \#bd & \#64 & $\# \mathrm{c} 4$ & \#af \\
\hline & $G$ & $\# 2 d$ & $\# 23$ & $\# 45$ & $\# 23$ & $\# 50$ & \#28 & $\# 56$ & \#27 & $\# 55$ & $\# 44$ \\
\hline & B & \#38 & $\# 2 \mathrm{a}$ & \#4f & $\# 2 \mathrm{e}$ & \#61 & $\# 2 \mathrm{e}$ & \#bd & $\# 4 \mathrm{~b}$ & $\# 75$ & \#67 \\
\hline \multirow{3}{*}{ Hijau } & $\mathrm{R}$ & $\# 56$ & $\# 15$ & \#6e & $\# 58$ & \#67 & $\# 40$ & $\# 63$ & \#38 & $\# 4$ & \#3 \\
\hline & $G$ & \#af & \#63 & \#99 & $\# 92$ & $\mathrm{Aa} 9$ & \#6a & $\# \mathrm{a} 9$ & $\# 7 \mathrm{e}$ & $\# \mathrm{ac}$ & $\# 9 c$ \\
\hline & $\mathrm{B}$ & $\# 7 \mathrm{~d}$ & $\# 27$ & $\# 5 \mathrm{~d}$ & $\# 48$ & $\# 77$ & $\# 25$ & $\# 49$ & $\# 28$ & $\# 80$ & $\# 71$ \\
\hline \multirow{3}{*}{ Biru } & $\mathrm{R}$ & $\# 58$ & $\# 20$ & \#64 & $\# 46$ & $\# 65$ & $\# 5 \mathrm{a}$ & $\# 58$ & $\# 42$ & $\# 1 d$ & $\# 2 \mathrm{a}$ \\
\hline & $G$ & \#a6 & $\# 86$ & \#a1 & \#84 & $\# 92$ & $\# 74$ & $\# 98$ & \#81 & \#38 & $\# 30$ \\
\hline & $\mathrm{B}$ & $\# \mathrm{c} 9$ & \#ba & $\# \mathrm{~d} 0$ & $\# a b$ & $\# \mathrm{~d} 2$ & \#99 & $\# \mathrm{c} 0$ & $\# a c$ & \#ef & $\# \mathrm{~d} 8$ \\
\hline
\end{tabular}

Keterangan :

[1]outdoor siang hari,[2] sore hari,[3] malam hari, [4]pagi hari,[5] menggunakan box dengan led

Dari data yang dikumpulkan dengan 5 kondisi ( indoor pagi hari,outdoor siang hari, outdoor sore hari, outdoor malam hari, dan menggunakan box berisi led ) didapatkan nilai piksel yang berbeda beda sehingga diperoleh nilai batas ambang maksimum dan minimum untuk sistem pembaca warna seperti yang ditunjukan pada Tabel 2.

Tabel 2. Tabel nilai batas maksimum dan minimum akhir

\begin{tabular}{|c|c|c|c|}
\hline Warna & RGB & Nilai max & Nilai min \\
\hline \multirow{3}{*}{ Merah } & $\mathrm{R}$ & $\#$ d4 & $\# 8 \mathrm{~d}$ \\
\cline { 2 - 4 } & $\mathrm{G}$ & $\# 55$ & $\# 23$ \\
\cline { 2 - 4 } & $\mathrm{B}$ & $\# 75$ & $\# 2 \mathrm{a}$ \\
\hline \multirow{3}{*}{ Hijau } & $\mathrm{R}$ & $\# 6 \mathrm{e}$ & $\# 3$ \\
\cline { 2 - 4 } & $\mathrm{G}$ & $\#$ af & $\# 63$ \\
\cline { 2 - 4 } & $\mathrm{B}$ & $\# 65$ & $\# 25$ \\
\hline \multirow{3}{*}{ Biru } & $\mathrm{R}$ & $\# 65$ & $\# 1 \mathrm{a}$ \\
\cline { 2 - 4 } & $\mathrm{G}$ & \#a9 & $\# 30$ \\
\cline { 2 - 4 } & $\mathrm{B}$ & \#ef & \#99 \\
\hline
\end{tabular}

\section{PENGUJIAN SISTEM}

\subsection{Pengujian tingkat akurasi}

Masing-masing pengujian tingkat akurasi ini dilakukan sebanyak 10 kali percobaan.

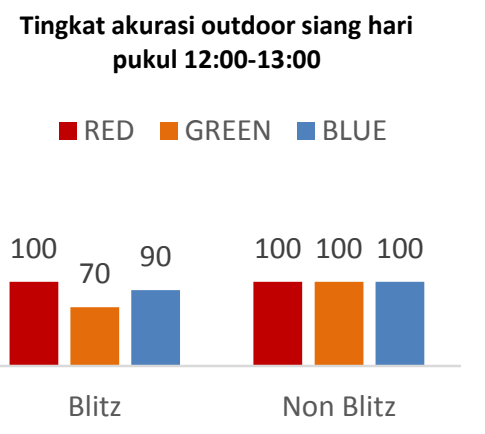

Gambar 6. Tingkat akurasi outdoor siang hari

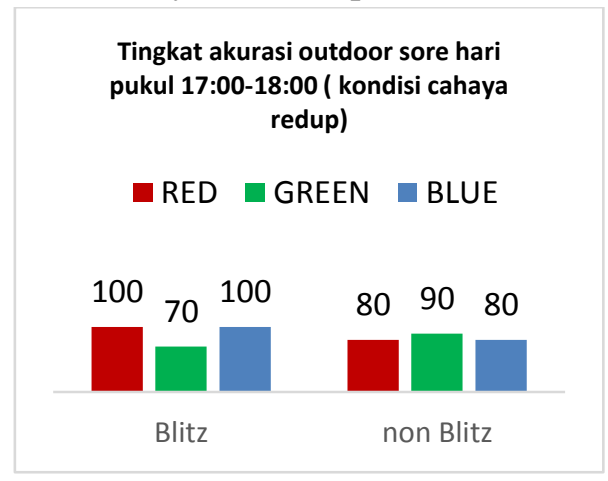

Gambar 7. Tingkat akurasi outdoor sore hari 


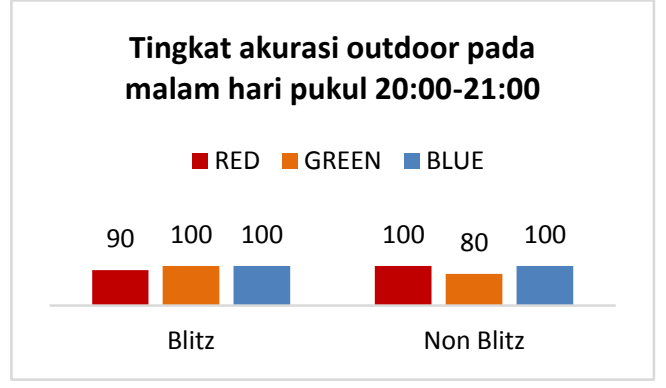

Gambar 8. Tingkat akurasi outdoor pada malam hari
Tingkat akurasi indoor pagi hari dan di dalam box

- RED - GREEN —BLUE

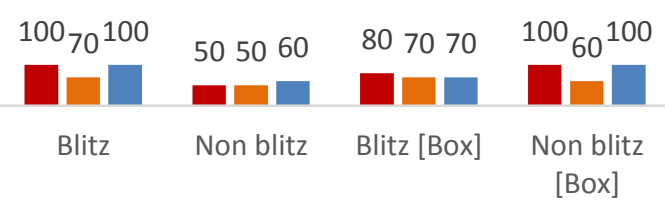

Gambar 9. Tingkat akurasi indoor di pagi hari dan di dalam box berisi led

Dari Gambar 6 dapat dilihat bahwa untuk kondisi pengambilan data outdoor di siang hari, aplikasi dapat mendeteksi warna R,G,dan B dengan tingkat akurasi maksimal (100\%) dengan prasyarat blitz kamera pada smartphone dimatikan. Gambar 7 menunjukkan untuk kondisi pengambilan data outdoor di sore hari, tingkat akurasi maksimal (100\%) diperoleh pada saat mendeteksi warna merah dan biru dengan keadaan blitz kamera diaktifkan. Sedangkan untuk kondisi pengujian outdoor dimalam hari seperti yang ditunjukkan Gambar 8, tingkat akurasi maksimal (100\%) diperoleh pada saat mendeteksi warna merah (blitz off), warna hijau (blitz on), dan warna biru ( blitz on/blitz off)

Berbeda dengan pengujian sebelumnya, pengujian pada kondisi pagi hari (indoor) seperti yang ditunjukan pada Gambar 9 tidak dipengaruhi oleh blitz kamera dari smartphone. Pada saat mendeteksi warna merah dan biru dengan blitz kamera smartphone dimatikan maupun diaktifkan memiliki tingkat akurasi maksimal $(100 \%)$.

\subsection{Pengujian dengan menggunakan bahan yang berbeda}

Pada pengujian ini digunakan satu kain flannel dan dua jenis kertas dengan berbahan dasar yang berbeda, dibawah ini adalah hasil dari pengujian yang dilakukan :

Tabel 3. Tabel hasil pengujian dengan bahan yang berbeda

\begin{tabular}{|c|c|c|c|}
\hline Jenis bahan & Warna & Terdeteksi & Tingkat akurasi \\
\hline \multirow{3}{*}{ (1)Kain flanel } & Biru & Tidak & \multirow{3}{*}{$30 \%$} \\
\hline & Merah & $\mathrm{Ya}$ & \\
\hline & Hijau & Tidak & \\
\hline \multirow{3}{*}{$\begin{array}{l}\text { (2)Kertas kilat } \\
\text { berwarna }\end{array}$} & Biru & Tidak & \multirow{3}{*}{$0 \%$} \\
\hline & Merah & Tidak & \\
\hline & Hijau & Tidak & \\
\hline \multirow{3}{*}{ (3) kertas creep } & Biru & Tidak & \multirow{3}{*}{$50 \%$} \\
\hline & Merah & $\mathrm{Ya}$ & \\
\hline & hijau & $\mathrm{Ya}$ & \\
\hline
\end{tabular}

Berdasarkan data pada Tabel.3 di atas, dapat disimpulkan bahwa tingkat akurasi tertinggi yaitu $50 \%$ diperoleh pada saat aplikasi mendeteksi warna merah dan hijau kertas creep.

\subsection{Pengujian berdasarkan jarak yang ditentukan}

Untuk mengetahui jarak maksimal yang masih dapat terdeteksi secara benar oleh aplikasi, maka dilakukan pengujian pendeteksi warna merah, hijau, dan biru dengan bahan kertas creep mulai dari jarak pengambilan $15 \mathrm{~cm}$ sampai dengan $45 \mathrm{~cm}$. Dari hasil pengujian tersebut, diperoleh jarak maksimal pendeteksian warna yaitu $20 \mathrm{~cm}$. 


\section{KESIMPULAN}

Bersasarkan hasil perancangan dan pengujian pada penelitian ini, maka dapat disimpulkan sebagai berikut:

1. Masukan pada kamera tergantung dari bahan yang digunakan dalam akuisasi citra, diantara 4 bahan yang digunakan untuk pengujian (kain flanel, kertas origami kilat, kertas warna origami biasa dan kertas creep), bahan yang paling baik adalah kertas origami biasa, yaitu memiliki tingkat akurasi $85 \%$.

2. Aplikasi ini di rancang untuk membantu para penderita warna agar dapat membedakan warna dengan benar. . Dengan tingkat akurasi total untuk masing-masing warna adalah merah : 90\%, hijau : $76 \%$, biru : $90 \%$.

3. Dari hasil pengujian tingkat akurasi yang dilakukan sebanyak 10 kali percobaan untuk masingmasing kondisi (indoor/outdoor pada pagi hari, siang hari, sore hari, dan malam hari menggunakan blitz/non blitz) diperoleh tingkat akurasi tertinggi yaitu $100 \%$ pada kondisi siang hari dengan tidak menggunakan blitz.

4. Aplikasi ini memiliki rata-rata waktu komputasi 6,67 detik

\section{DAFTAR PUSTAKA}

[1] Raharjo Budi , Heryanto Imam, haryono Arif.2010.Mudah Belajar Java .Informatika, Bandung.

[2] Safaat Nazruddin H. 2011. Pemograman Aplikasi Mobile Smartphone dan TabletPC Berbasis Android. Informatika, Bandung.

[3] https://id.wikipedia.org/wiki/Aplikasi

[4] http://www.academia.edu/2239550/Proposal TA

[5] http://siandroid.blogspot.com/2013/06/versi-dan-tingkat-android.html

[6] http://id.wikipedia.org/wiki/Android (sistem operasi)

[7] http://www.vedcmalang.com/pppptkboemlg/index.php/artikel-coba-2/teknologiinformasi/825-arsitektur-sistem-operasi-android

[8] http://bpptik.kominfo.go.id/index.php/id/artikel/142-sejarah-singkat-java

[9] http://www.termasmedia.com/2012-05-29-02-56-17/java/235-beberapa-karakteristik-bahasapemrograman-java.html

[10] http://bayduaenam.blogspot.com/2011/06/eclipse.html 